Tusen takk for at du vil være med videre i barnE-mat studien!

Det enkleste er å fylle ut spørreskjemaet ved en dataskjerm. Du navigerer i skjemaet ved å trykke på pilene / "neste-knappen" nederst på siden.

Etter noen innledende spørsmål er spørreskjemaet todelt:

Første del av spørreskjemaet handler om barnet som deltar i undersøkelsen. Du vil trenge barnets helsekort for opplysninger om vekt og høyde, ha gjerne dette klart før du begynner. Andre del er om deg som er mor eller far til barnet.

Lykke til!

Hva er din relasjon til barnet som deltar i undersøkelsen?

(1) $\square$ Jeg er mor

(2) $\square$ Jeg er far

(3) $\square$ Jeg er ingen av delene, beskriv

Hva er barnets fødselsdato?

Må skrives år-mnd-dag, f.eks. 2015-06-26

Hva er barnets kjønn?

(1) $\square$ jente

(2) $\square$ gutt

Er barnet som deltar i denne studien ditt eneste barn?

(0) $\square \mathrm{Ja}$

(1) $\square$ Nei

Hvor mange barn har du?
(1) $\square$ To
(2) $\square$ Tre
(3) $\square$ Fire eller fler 
Var du i gruppen som hadde tilgang til nettstedet og filmene i barnE-mat? (intervensjonsgruppen)
(1) $\square \mathrm{Ja}$
(2) $\square \mathrm{Nei}$

Så du de månedlige tema-filmene?
(1) $\square \mathrm{Ja}$, så alle filmene
(2) $\square \mathrm{Ja}$, så de fleste filmene
(3) $\square \mathrm{Ja}$, så cirka halvparten av filmene
(4) $\square \mathrm{Ja}$, så en eller to av filmene
(5) $\square$ Nei, så ingen av filmene

Så du på mat-filmene eller oppskriftene?
(1) $\square \mathrm{Ja}$, så alle filmene
(2) $\square \mathrm{Ja}$, så de fleste filmene
(3) $\square \mathrm{Ja}$, så cirka halvparten av filmene
(4) $\square \mathrm{Ja}$, så en eller to av filmene
(5) $\square$ Nei, så ingen av filmene

Nå følger noen spørsmål om barnets vekst og utvikling det siste året.

Ta utgangspunkt i barnets helsekort fra helsestasjonen og fyll inn dato for undersøkelse, vekt og lengde i spørsmålene. Har du ikke aktuelle vekt- eller høydemål, kan du gå videre i skjemaet.

Undersøkelse ved ca. 18 mnd. alder:

Dato for undersøkelse

Vekt i gram

Lengde i $\mathrm{cm}$

Undersøkelse ved ca. to års alder:

Dato for undersøkelse

Vekt i gram

Lengde i cm 
Nå følger noen spørsmål om barnets kosthold og matvaner ved to års-alder:

Hvor ofte pleier barnet ditt å spise følgende måltider i løpet av en uke?

\begin{tabular}{|c|c|c|c|c|c|c|c|c|}
\hline & $\begin{array}{l}\text { Aldri/sjel } \\
\text { den }\end{array}$ & $\begin{array}{c}1 \\
\text { gang/uke }\end{array}$ & $2 \mathrm{~g} / \mathrm{u}$ & $3 \mathrm{~g} / \mathrm{u}$ & $4 \mathrm{~g} / \mathrm{u}$ & $5 \mathrm{~g} / \mathrm{u}$ & $6 \mathrm{~g} / \mathrm{u}$ & Hver dag \\
\hline Frokost & (1) $\square$ & (2) $\square$ & (3) $\square$ & (4) $\square$ & (5) $\square$ & (6) $\square$ & (7) $\square$ & (8) $\square$ \\
\hline Formiddagsmat/lunsj & (1) $\square$ & (2) $\square$ & (3) $\square$ & (4) $\square$ & (5) $\square$ & (6) $\square$ & (7) $\square$ & (8) $\square$ \\
\hline Mellommåltid før middag & (1) $\square$ & (2) $\square$ & (3) $\square$ & (4) $\square$ & (5) $\square$ & (6) $\square$ & (7) $\square$ & (8) $\square$ \\
\hline Middag & (1) $\square$ & (2) $\square$ & (3) $\square$ & (4) $\square$ & (5) $\square$ & (6) $\square$ & (7) $\square$ & (8) $\square$ \\
\hline Mellommåltid etter middag & (1) $\square$ & (2) $\square$ & (3) $\square$ & (4) $\square$ & (5) $\square$ & (6) $\square$ & (7) $\square$ & (8) $\square$ \\
\hline Kveldsmat & (1) $\square$ & (2) $\square$ & (3) $\square$ & (4) $\square$ & (5) $\square$ & (6) $\square$ & (7) $\square$ & (8) $\square$ \\
\hline $\begin{array}{l}\text { Andre } \\
\text { nåltider/mellommåltider }\end{array}$ & (1) $\square$ & (2) $\square$ & (3) $\square$ & (4) $\square$ & (5) $\square$ & (6) $\square$ & (7) $\square$ & (8) $\square$ \\
\hline
\end{tabular}

Hvor ofte spiser barnet følgende måltider sammen med familien nå?

Dvs. samtidig som en voksen spiser samme måltid

Aldri/sjelden 1-3 ganger per uke 4-6 ganger per uke Hver dag

Frokost

Formiddagsmat/lunsj

Middag

Kveldsmat
(1)

(1) $\square$

(1) $\square$

(1) $\square$
(2)

(2) $\square$

(2) $\square$

(2) $\square$
(3) $\square$

(3) $\square$

(3) $\square$

(3) $\square$
(4)

(4) $\square$

(4) $\square$

(4) $\square$

Er det du som oftest gir barnet mat?
(1) $\square \mathrm{Ja}$
(2) $\square$ Nei
(3) $\square$ Deler likt 
Pleier barnet å bli matet (dvs. en voksen holder skjeen eller deler opp maten og gir den bit for bit), eller spiser det selv?

$\begin{array}{cccc}\begin{array}{c}\text { Spiser alltid } \\ \text { selv }\end{array} & \begin{array}{c}\text { Spiser som } \\ \text { oftest selv }\end{array} \quad \text { Både og } & \begin{array}{c}\text { Blir som oftest } \\ \text { matet }\end{array}\end{array}$

Frokost
(1) $\square$
(3)
(4) $\square$
(5) $\square$
(2) $\square$

Lunsj
(1) $\square$
(3) $\square$

(4) $\square$

(5)

(2)

Ettermiddagsmat (måltid etter lunsj og før middag)

(1)

(3) $\square$

(4) $\square$

(5) $\square$

(2) $\square$

Middag
(1) $\square$

(3) $\square$

(4)

(5)

(2)

Kveldsmat
(1) $\square$
(3)
(4) $\square$
(5) $\square$
(2) $\square$

Andre

måltider/mellommåltider

(1) $\square$ (3)

(4)

(4) $\square$

(5)

(2)

Hvor ofte stemmer utsagnene under på barnets måltider nå?

Nesten alltid

Ofte

Av og til

Sjelden

Nesten aldri

Barnet spiser samme

middagsmat som resten av

(1)

(6)

(7) $\square$

(8)

(9)

familien

Jeg/vi lager egen

middagsmat til barnet

(1)

(7) $\square$

(8)

(9) $\square$

Barnet sitter ved bordet når hun/han spiser

(1)

(1) $\square$

TV/nettbrett/smarttelefon mens hun/han spiser
(6) $\square$

口 (6)

(6)

(6) $\square$

$\square$
(7) $\square$

(8)

(8) $\square$

(9)

Har eller har barnet hatt problemer med spising/mat? Her kan du sette flere kryss

(1) $\square$ Nei, har ingen problemer 

(2) $\square$ Ja, dårlig matlyst/småspist
(3) $\square$ Ja, liker få matvarer
(4) $\square \mathrm{Ja}$, vanskelig med tilvenning til familiens kosthold
(5) $\square \mathrm{Ja}$, allergi/intoleranse mot enkelte matvarer
(6) $\square \mathrm{Ja}$, andre problemer - beskriv

Hvor ofte får barnet følgende å drikke nå for tiden?

\begin{tabular}{|c|c|c|c|c|c|c|c|c|}
\hline & $\begin{array}{c}\text { Aldri/sjel } \\
\text { den }\end{array}$ & $\begin{array}{c}1-3 \\
\text { ganger } \\
\text { per uke }\end{array}$ & $\begin{array}{l}4-6 \\
\text { ganger } \\
\text { per uke }\end{array}$ & $\begin{array}{c}1 \text { gang } \\
\text { per døgn }\end{array}$ & $\begin{array}{l}2 \text { gange } \\
\text { per døg }\end{array}$ & $\begin{array}{l}3 \text { ganger } \\
\text { per døg }\end{array}$ & $\begin{array}{l}4 \text { ganger } \\
\text { per døgn }\end{array}$ & $\begin{array}{c}5 \text { eller } \\
\text { flere } \\
\text { ganger } \\
\text { per døgr }\end{array}$ \\
\hline Vanlig søt melk, alle typer & (1) $\square$ & (2) $\square$ & (3) $\square$ & (4) $\square$ & (5) & (6) $\square$ & (7) $\square$ & (8) $\square$ \\
\hline $\begin{array}{l}\text { Surmelk, alle typer (yoghurt, } \\
\text { kulturmelk o.I.) }\end{array}$ & (1) $\square$ & (2) $\square$ & (3) $\square$ & (4) $\square$ & (5) $\square$ & (6) $\square$ & (7) $\square$ & (8) $\square$ \\
\hline Sjokolademelk, alle typer & (1) $\square$ & (2) $\square$ & (3) $\square$ & (4) $\square$ & (5) $\square$ & (6) $\square$ & (7) $\square$ & (8) $\square$ \\
\hline Vann & (1) $\square$ & (2) $\square$ & (3) $\square$ & (4) $\square$ & (5) $\square$ & (6) $\square$ & (7) $\square$ & (8) $\square$ \\
\hline
\end{tabular}

Hvor ofte får barnet følgende å drikke nå for tiden?
Saft, sukret
(1) $\square$
(2) $\square$
(3)
(4)
(5)
(6)
$\square \quad(7) \square$
(8)
Saft, kunstig søtet
(1) $\square \quad$ (2)
(3) $\square \quad$ (4)
(5)
(6) $\square \quad$ (7) $\square$
(8) $\square$
Juice
(1) $\square \quad$ (2)
(3) $\square \quad$ (4)
(5)
(6)
(7) $\square$
(8) $\square$
Brus, sukret
(1) $\square \quad$ (2) $\square$
(3) $\square \quad$ (4)
(5)
(6) $\square \quad$ (7) $\square$
(8) $\square$
Lettbrus, kunstig søtet
(1) $\square \quad$ (2) $\square$
(3) $\square \quad$ (4)
(5) $\square$
(6)
(7) $\square$
(8) $\square$

Hvor ofte spiser barnet følgende mat nå for tiden?

Hvor ofte?

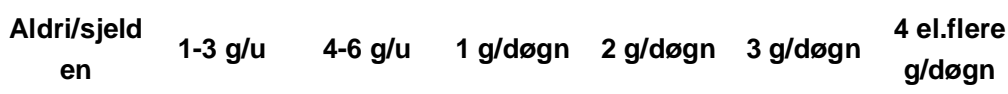

Industrifremstilt grøt, alle typer
(1)
(2) $\square$
(3) $\square$
(4) $\square$
(5) $\square$
(6) $\square$
(7) $\square$ 


\section{Hvor ofte?}

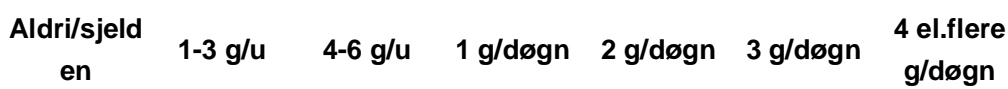

Hjemmelaget grøt av

grovt/sammalt mel, hirse eller

(1) $\square$

(2) $\square$

(3) $\square$

(4) $\square$

(5) $\square$

(6) $\square$

(7) $\square$

havregryn/havremel

Hjemmelaget grøt av fint/hvitt mel, kavring, semule, ris, eller mais
(1) $\square$
(2) $\square$
(3) $\square$
(4) $\square$
(5) $\square$
(6) $\square$
(7) $\square$

Hvor ofte spiser barnet følgende mat nå for tiden?

\begin{tabular}{|c|c|c|c|c|c|c|c|c|c|}
\hline & $\begin{array}{c}\text { Aldri/ikt } \\
e \\
\text { forsøkt }\end{array}$ & $\begin{array}{c}\text { Under } 1 \\
\text { g/uke }\end{array}$ & $\begin{array}{c}1-2 \\
\text { g/uke }\end{array}$ & $\begin{array}{c}3-4 \\
\text { g/uke }\end{array}$ & $\begin{array}{c}5-6 \\
\text { g/uke }\end{array}$ & $\begin{array}{c}1 \\
\text { g/døgn }\end{array}$ & $\begin{array}{c}2 \\
\text { g/døgn }\end{array}$ & $\begin{array}{c}3 \\
g / \operatorname{døg} n\end{array}$ & $\begin{array}{c}4 \mathrm{~g} \text { elle } \\
\text { mer/døs } \\
n\end{array}$ \\
\hline Brød med leverpostei & (1) $\square$ & (8) $\square$ & (2) $\square$ & (3) $\square$ & (9) $\square$ & (4) $\square$ & (5) $\square$ & (6) $\square$ & (7) $\square$ \\
\hline Brød med annet kjøttpålegg & (1) $\square$ & (8) $\square$ & (2) $\square$ & (3) $\square$ & (9) $\square$ & (4) $\square$ & (5) $\square$ & (6) $\square$ & (7) $\square$ \\
\hline Brød med fiskepålegg & (1) $\square$ & (8) $\square$ & (2) $\square$ & (3) $\square$ & (9) $\square$ & (4) $\square$ & (5) $\square$ & (6) $\square$ & (7) $\square$ \\
\hline Brød med ost & (1) $\square$ & (8) $\square$ & (2) $\square$ & (3) $\square$ & (9) $\square$ & (4) $\square$ & (5) $\square$ & (6) $\square$ & (7) $\square$ \\
\hline Brød med syltetøy/honning & (1) $\square$ & (8) $\square$ & (2) $\square$ & (3) $\square$ & (9) $\square$ & (4) $\square$ & (5) $\square$ & (6) $\square$ & (7) $\square$ \\
\hline Brød med annet pålegg & (1) $\square$ & (8) $\square$ & (2) $\square$ & (3) $\square$ & (9) $\square$ & (4) $\square$ & (5) $\square$ & (6) $\square$ & (7) \\
\hline
\end{tabular}

Hvor ofte spiser barnet følgende mat nå for tiden?

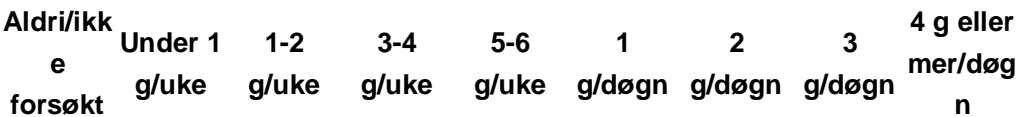

Kjøtt, kjøttdeig, kjøttboller, pølse o.l.
(1)

(8)

(2) $\square$

(3) $\square$

(9) $\square$

(4)

(5)

(6) $\square \quad$ (7) $\square$

Fisk, fiskeboller-/kaker/-

pudding o.I.
(1)
(8)

(2) $\square$

(3) $\square$

(9)

(4)

(5) $\square$

(6) $\square \quad$ (7) $\square$

Pannekaker
(1)

(8)

(2) $\square \quad$ (3) $\square$

(9)

(4) $\square$

(5)

(6) $\square \quad$ (7) $\square$

Pizza

(1) $\square$

(8) $\square$

(2) $\square$

(3) $\square$

(9) $\square$

(4) $\square$

(5) $\square$

(6) $\square \quad$ (7) $\square$

Pasta/ris, vanlig type

(1) $\square \quad$ (8)

(2) $\square$

(3) $\square$

(9) $\square$

(4) $\square$

(5) $\square$

(6) $\square \quad$ (7) $\square$

Pasta/ris, fullkornstype

(1) $\square \quad$ (8) $\square \quad$ (2) $\square$

(3) $\square$

(9) $\square$

(4) $\square$

(5) $\square$

(6) $\square \quad$ (7) $\square$ 
Hvor ofte spiser barnet følgende mat nå for tiden?

\begin{tabular}{|c|c|c|c|c|c|c|c|c|c|}
\hline & $\begin{array}{c}\text { Aldri/ikk } \\
\text { e } \\
\text { forsøkt }\end{array}$ & $\begin{array}{l}\text { Under } 1 \\
\mathrm{~g} / \mathrm{uke}\end{array}$ & $\begin{array}{c}1-2 \\
\text { g/uke }\end{array}$ & $\begin{array}{c}3-4 \\
\text { g/uke }\end{array}$ & $\begin{array}{c}5-6 \\
\text { g/uke }\end{array}$ & $\begin{array}{c}1 \\
\text { g/døgn }\end{array}$ & $\begin{array}{c}2 \\
g / d ø g n\end{array}$ & $\begin{array}{c}3 \\
g / d ø g n\end{array}$ & $\begin{array}{c}4 \mathrm{~g} \text { eller } \\
\text { mer } / \mathrm{d} ø \mathrm{~g} \\
\mathrm{n}\end{array}$ \\
\hline Kaker, vafler, søt kjeks o.I. & (1) $\square$ & (8) $\square$ & (2) $\square$ & (3) $\square$ & (9) $\square$ & (4) $\square$ & (5) $\square$ & (6) $\square$ & (7) $\square$ \\
\hline Dessert/iskrem & (1) $\square$ & (8) $\square$ & (2) $\square$ & (3) $\square$ & (9) $\square$ & (4) $\square$ & (5) $\square$ & (6) $\square$ & (7) $\square$ \\
\hline Sjokolade & (1) $\square$ & (8) $\square$ & (2) $\square$ & (3) $\square$ & (9) $\square$ & (4) $\square$ & (5) $\square$ & (6) $\square$ & (7) $\square$ \\
\hline Smågodt, seigmenn o.I. & (1) $\square$ & (8) $\square$ & (2) $\square$ & (3) $\square$ & (9) $\square$ & (4) $\square$ & (5) $\square$ & (6) $\square$ & (7) $\square$ \\
\hline Chips/potetgull o.I. & (1) $\square$ & (8) $\square$ & (2) $\square$ & (3) $\square$ & (9) $\square$ & (4) $\square$ & (5) $\square$ & (6) $\square$ & (7) $\square$ \\
\hline
\end{tabular}

Hvor ofte spiser barnet følgende grønnsaker nå for tiden?

Ta med både rå, kokte og mosede grønnsaker

\begin{tabular}{|c|c|c|c|c|c|c|c|c|c|}
\hline & $\begin{array}{c}\text { Aldri/ikk } \\
\text { e } \\
\text { forsøkt }\end{array}$ & $\begin{array}{c}\text { Under } 1 \\
\text { g/uke }\end{array}$ & $\begin{array}{c}1-2 \\
\text { g/uke }\end{array}$ & $\begin{array}{c}3-4 \\
\text { g/uke }\end{array}$ & $\begin{array}{c}5-6 \\
\text { g/uke }\end{array}$ & $\begin{array}{c}1 \\
g / d ø g n\end{array}$ & $\begin{array}{c}2 \\
g / d ø g n\end{array}$ & $\begin{array}{c}3 \\
\text { g/døgn }\end{array}$ & $\begin{array}{c}4 \mathrm{~g} \text { eller } \\
\text { mer/døg } \\
\mathrm{n}\end{array}$ \\
\hline tet & (1) $\square$ & (8) $\square$ & (2) $\square$ & (3) $\square$ & (9) $\square$ & (4) & (5) & (6) $\square$ & (7) $\square$ \\
\hline Arot & (1) & (8) $\square$ & (2) $\square$ & (3) $\square$ & (9) $\square$ & (4) & (5) $\square$ & (6) $\square$ & (7) \\
\hline Irot & (1) $\square$ & (8) $\square$ & (2) $\square$ & (3) $\square$ & (9) $\square$ & 口 & 口 & (6) $\square$ & (7) $\square$ \\
\hline tpotet & (1) $\square$ & (8) $\square$ & (2) $\square$ & (3) $\square$ & (9) $\square$ & 口 & 口 & (6) $\square$ & (7) \\
\hline mkål & (1) $\square$ & (8) $\square$ & (2) $\square$ & (3) $\square$ & (9) $\square$ & 口 & 口 & (6) $\square$ & (7) \\
\hline okkoli & (1) $\square$ & (8) $\square$ & (2) $\square$ & (3) $\square$ & (9) $\square$ & 口 & 口 & (6) $\square$ & (7) \\
\hline nn salat & (1) $\square$ & (8) & (2) $\square$ & (3) $\square$ & (9) $\square$ & 口 & 口 & (6) $\square$ & (7) $\square$ \\
\hline nat & (1) $\square$ & (8) $\square$ & (2) $\square$ & (3) $\square$ & (9) $\square$ & 口 & 口 & (6) $\square$ & \\
\hline
\end{tabular}

Hvor ofte spiser barnet følgende grønnsaker nå for tiden?

Ta med både rå, kokte og mosede grønnsaker

$\begin{array}{ccccccccc}\text { Aldri/ikk } & & & & & & \\ \begin{array}{c}e \\ \text { Under } 1\end{array} & 1-2 & 3-4 & 5-6 & 1 & 2 & 3 & \text { eller } \\ \text { forsøkt } & \text { g/uke } & \text { g/uke } & \text { g/uke } & \text { g/uke } & \text { g/døgn } & \text { g/døgn } & \text { g/døgn } & n \\ n\end{array}$

Agurk

(1) $\square \quad$ (8) $\square \quad$ (2) $\square$

(3) $\square$

(9) $\square$

(4) $\square$

(5) $\square$

(6) $\square \quad(7) \square$

Tomat

(1) $\square \quad(8)$

(8) $\square$ (2) $\square$

(3) $\square$

(9) $\square$

(4) $\square$

(5) $\square$

(6) $\square \quad$ (7) $\square$

Mais

(1) $\square \quad$ (8) $\square$

(2) $\square$

(3) $\square$

(9) $\square$

(4) $\square$

(5) $\square$

(6) $\square \quad$ (7) $\square$ 
Paprika

Erter/bønner

Frossen grønnsaksblanding

Råkost $\begin{array}{ccccccccc}\text { Aldri/ikk } & & & & & \\ \quad \text { Under } 1 & 1-2 & 3-4 & 5-6 & 1 & 2 & 3 & \text { g eller } \\ \text { forsøkt } & \text { g/uke } & \text { g/uke } & \text { g/uke } & \text { g/uke } & \text { g/døgn } & \text { g/døgn } & \text { g/døgn } & \text { mer/døg } \\ n\end{array}$
(1) $\square$
(8) $\square$
(2) $\square$
(3) $\square$
(9) $\square$
(4) $\square$
(5) $\square$
(6) $\square \quad$ (7) $\square$

(1) $\square$

(8) $\square$

(2) $\square$

(3) $\square$

(9) $\square$

(4) $\square$

(5) $\square$

(6) $\square$ (7) $\square$

(1) $\square$

(8) $\square$

(2) $\square$

(3) $\square$

(9) $\square$

(4) $\square$

(5) $\square$

(6) $\square$ (7) $\square$

(1) $\square$

(8) $\square$

(2) $\square$

(3) $\square$

(9) $\square$

(4) $\square$

(5) $\square$

(6) $\square \quad$ (7) $\square$

Hvor ofte spiser barnet følgende frukt og bær nå for tiden?

\begin{tabular}{|c|c|c|c|c|c|c|c|c|c|}
\hline & $\begin{array}{c}\text { Aldri/ikk } \\
\text { e } \\
\text { forsøkt }\end{array}$ & $\begin{array}{c}\text { Under } 1 \\
\text { g/uke }\end{array}$ & $\begin{array}{c}1-2 \\
\text { g/uke }\end{array}$ & $\begin{array}{c}3-4 \\
\text { g/uke }\end{array}$ & $\begin{array}{c}5-6 \\
\text { g/uke }\end{array}$ & $\begin{array}{c}1 \\
\text { g/døgn }\end{array}$ & $\begin{array}{c}2 \\
\text { g/døgn }\end{array}$ & $\begin{array}{c}3 \\
g / d ø g n\end{array}$ & $\begin{array}{c}4 \mathrm{~g} \text { eller } \\
\mathrm{mer} / \mathrm{d} ø \mathrm{~g} \\
\mathrm{n}\end{array}$ \\
\hline Appelsin/klementin o.l. & (1) $\square$ & (8) $\square$ & (2) $\square$ & (3) $\square$ & (9) $\square$ & (4) $\square$ & (5) $\square$ & (6) $\square$ & (7) $\square$ \\
\hline Banan & (1) $\square$ & (8) $\square$ & (2) $\square$ & (3) $\square$ & (9) $\square$ & (4) $\square$ & (5) $\square$ & (6) $\square$ & (7) $\square$ \\
\hline Eple & (1) $\square$ & (8) $\square$ & (2) $\square$ & (3) $\square$ & (9) $\square$ & (4) $\square$ & (5) $\square$ & (6) $\square$ & (7) $\square$ \\
\hline Pære & (1) $\square$ & (8) $\square$ & (2) $\square$ & (3) $\square$ & (9) $\square$ & (4) $\square$ & (5) $\square$ & (6) $\square$ & (7) \\
\hline Plomme & (1) $\square$ & (8) $\square$ & (2) $\square$ & (3) $\square$ & (9) $\square$ & (4) $\square$ & (5) $\square$ & (6) $\square$ & (7) \\
\hline Druer & (1) $\square$ & (8) $\square$ & (2) $\square$ & (3) $\square$ & (9) $\square$ & (4) $\square$ & (5) $\square$ & (6) $\square$ & (7) $\square$ \\
\hline
\end{tabular}

Hvor ofte spiser barnet følgende frukt og bær nå for tiden?

Kiwi $\begin{array}{ccccccccc}\text { Aldri/ikk } & & & & & \\ \text { e } & \text { Under } 1 & 1-2 & 3-4 & 5-6 & 1 & 2 & 3 & \begin{array}{c}\text { eller } \\ \text { mer/døg }\end{array} \\ \text { forsøkt } & \text { g/uke } & \text { g/uke } & \text { g/uke } & \text { g/uke } & \text { g/døgn } & \text { g/døgn } & \text { g/døgn } & n\end{array}$

Melon

(1)

(8)

(2) $\square$

(3) $\square \quad$ (9)

9) $\square \quad(4)$

(4) $\square \quad$ (5)

(5) $\square$

(6) $\square \quad$ (7)

Mango

(1) $\square$

(8) $\square$

(2) $\square$

(3) $\square$

(9) $\square$

(4) $\square$

(5) $\square$

(6) $\square \quad$ (7) $\square$

Bær, alle typer

(1) $\square$ (8)

(2) $\square$

(3) $\square$

(9) $\square$

(4) $\square$

(5) $\square$

(6) $\square \quad$ (7)

(1) $\square \quad$ (8) $\square$

(2) $\square$

(3) $\square$

(9) $\square$

(4) $\square$

(5) $\square$

(6) $\square \quad$ (7) $\square$

Får barnet hjemmelaget middagsmat eller ferdigkjøpt (industrifremstilt) barnemat på glass eller pose?

(1) $\square$ Bare hjemmelaget 

(2) $\square$ Mest hjemmelaget
(3) $\square$ Omtrent halvparten av hvert
(4) $\square$ Mest ferdigkjøpt
(5) $\square$ Bare ferdigkjøpt

Får barnet tran eller vitamintilskudd?
(1) $\square \mathrm{Ja}$
(2) $\square$ Nei

Angi hva slags type kosttilskudd, mengde og hyppighet.

\section{Antall t-skjeer per gang? Hvor ofte?}

$\begin{array}{ccccccc}\text { lkke } & & 2 & 3 & \begin{array}{c}4 \text { eller } \\ \text { fler }\end{array} \text { Ikke aktuelt daglig } & \text { av og til }\end{array}$
Tran
(1)
(2) $\square(5)$
(5) $\square$ (4) $\square$ (3)
(1) $\square$
(2) $\square$
(3) $\square$

Flytende vitamin- / multivitamintilskudd
(1)
(2) $\square \quad(5)$
(4) $\square$ (3)
(3) $\square \quad$ (1)
(2)
(3)

Hva slags konsistens er det på maten barnet ditt spiser nå?

$$
\text { Spiser ofte }
$$

(1)

(1)

(1)

(1)

(1)
$\square$

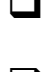

$\square$
Spiser noen
ganger

Spiser sjelden

Pureer/helt glatt mat

(3) aldri/spiste før tilbudt/forsøkt

Finmost mat

Most mat med klumper

Finhakket/kuttet mat

Fingermat/mat i biter

(2) $\square$

(2) $\square$

(2) $\square$

(2) $\square$

(2) $\square$
(3)

(3)

(3)

(3)
(5)

(5)

(5)

(5)

(5)
(4)

(4)

(4) 
Les utsagnene under og kryss av for det svaralternativet som passer best på ditt barns spiseatferd

Barnet mitt elsker mat

Aldri

Sjelden

Noen ganger

Ofte

Alltid

Barnet mitt spiser mer når

hun/han er bekymret

(1) $\square$

(2) $\square$

(3) $\square$

(4) $\square$

(5)

Barnet mitt har stor appetitt

(1)

(2) $\square$

(3) $\square$

(4)

(5) $\square$

(1) $\square$

(2) $\square$

(3) $\square$

(4) $\square$

(5) $\square$

Barnet mitt bruker kort tid på måltidet

(1)

(2) $\square$

(3) $\square$

(4)

(5) $\square$

Barnet mitt er interessert i mat
(1)

(2) $\square$

(3) $\square$

(4)

(5) $\square$

Barnet mitt spør alltid om noe å drikke

(1)

(2) $\square$

(3) $\square$

(4)

(5)

Barnet mitt nekter å spise ny mat de første gangene det tilbys

(1)

(2) $\square$

(3) $\square$

(4)

(5)

Barnet mitt spiser sakte
(1) $\square$

(2) $\square$

(3) $\square$

(4)

(5) $\square$

Barnet mitt spiser mindre når hun/han er sint
(1)

(2) $\square$

(3)

(4)

(5)

\section{Les utsagnene under og kryss av for det svaralternativet som passer best på ditt} barns spiseatferd

$\begin{array}{lccccc}\text { Barnet mitt liker å smake ny } & \text { Aldri } & \text { Sjelden } & \text { Noen ganger } & \text { Ofte } & \text { Alltid } \\ \text { mat } & \text { (1) } \square & \text { (2) } \square & \text { (3) } \square & \text { (4) } \square & \text { (5) } \square \\ \begin{array}{l}\text { Barnet mitt spiser mindre når } \\ \text { hun/han er trøtt }\end{array} & \text { (1) } \square & \text { (2) } \square & \text { (3) } \square & \text { (4) } \square & \text { (5) } \square \\ \text { Barnet mitt ber alltid om mat } & \text { (1) } \square & \text { (2) } \square & \text { (3) } \square & \text { (4) } \square & \text { (5) } \\ \begin{array}{l}\text { Barnet mitt spiser mer når } \\ \text { hun/han er irritert }\end{array} & \text { (1) } \square & \text { (2) } \square & \text { (3) } \square & \text { (4) } \square & \text { (5) } \\ \begin{array}{l}\text { Hvis hun/han fikk lov, ville } \\ \text { barnet mitt spise for mye }\end{array} & \text { (1) } \square & \text { (2) } \square & \text { (3) } \square & \text { (4) } \square & \text { (5) } \square \\ \begin{array}{l}\text { Barnet mitt spiser mer når } \\ \text { hun/han er engstelig }\end{array} & \text { (1) } \square & \text { (2) } \square & \text { (3) } \square & \text { (4) } \square & \text { (5) } \square\end{array}$




\begin{tabular}{|c|c|c|c|c|}
\hline & Aldri & Sjelden & Noen ganger & Ofte \\
\hline $\begin{array}{l}\text { Barnet mitt liker mye } \\
\text { forskjellig mat }\end{array}$ & (1) $\square$ & (2) $\square$ & (3) $\square$ & (4) $\square$ \\
\hline $\begin{array}{l}\text { Barnet mitt spiser ikke opp } \\
\text { maten sin }\end{array}$ & (1) $\square$ & (2) $\square$ & (3) $\square$ & (4) $\square$ \\
\hline $\begin{array}{l}\text { Barnet mitt bruker mer enn } 30 \\
\text { min. på å bli ferdig med et } \\
\text { måltid }\end{array}$ & (1) $\square$ & (2) $\square$ & (3) $\square$ & (4) $\square$ \\
\hline
\end{tabular}

Les utsagnene under og kryss av for det svaralternativet som passer best på ditt barns spiseatferd

Aldri Sjelden Noen ganger Ofte Allid

Hvis barnet mitt fikk velge, så

ville hun/han spise det meste

(1) $\square$ (2) $\square$

(3) $\square$

(4)

(5) $\square$

av tiden

Barnet mitt gleder seg til måltidene

(1) $\square$

(2) $\square$

(3) $\square$

(4)

(5)

Barnet mitt blir mett før hun/han har spist opp
(1) $\square$
(2) $\square$
(3) $\square$
(4)
(5) $\square$

Barnet mitt liker å spise

(1) $\square$ (2)

(2) $\square$

(3) $\square$

(4)

(5)

Barnet mitt spiser mer når hun/han er glad
(1)

(2) $\square$

(3) $\square$

(4)

(5)

Barnet mitt er sjelden fornøyd med maten hun/han får

(1)

(2) $\square$

(3) $\square$

(4)

(5)

servert

Barnet mitt spiser mindre når hun/han er lei seg eller

(1) opprørt

Barnet mitt blir fort mett

Barnet mitt spiser mer når hun/han ikke har noe å gjøre
(1) $\square$

(1)
(2) $\square$

(2) $\square$

(2) $\square$
(3) $\square$

(3) $\square$

(3) $\square$
(4) $\square$

(4)

(4)
(5)

(5) 
Les utsagnene under og kryss av for det svaralternativet som passer best på ditt barns spiseatferd

$\begin{array}{llll}\text { Aldri } & \text { Sjelden } & \text { Noen ganger } & \text { Ofte }\end{array}$

Selv om barnet mitt er mett, så har hun/han plass til

(1)

favorittmaten $\sin$

Hvis hun/han fikk muligheten, så ville barnet mitt drikke hele dagen lang

Barnet mitt klarer ikke å spise et vanlig måltid hvis hun/han har spist et mellom-måltid like før

Hvis hun/han fikk muligheten, så ville barnet mitt alltid hatt noe å drikke

Barnet mitt er interessert i å smake mat som hun/han ikke har smakt før

Barnet mitt bestemmer seg for at hun/han ikke liker enkelte matsorter, selv uten å ha smakt

Hvis hun/han fikk muligheten, så ville barnet mitt hatt mat $\mathrm{i}$ munnen hele tiden

Barnet mitt spiser stadig saktere utover i måltidet
(1)

(1) $\square$

(1)

(1) $\square$

(1)
(1) $\square$

(2) $\square$

(3)

(3) $\square$

(4)

(5)

(2) $\square$

(3) $\square$

(4) $\square$

(5)

(2)

(3) $\square$

(4)

(5)

5)

(4) $\square$

$\square$

(3) $\square$

(4) $\square$

(5) $\square$

(2) $\square$

(3) $\square$

(4) $\square$

(5)

(2)

(3) $\square$

(4)

(5)

$\square$

(2) $\square$

(3) $\square$

(4)

(5)

Hvor enig er du i følgende påstander?

Barnet mitt stoler ikke på ukjent mat

(1)

(1) som er i maten, vil hun/han ikke smake
(2)

(3)

(4)

(4) 
Svært uenig Noe uenig $\quad$ Litt enig $\quad$ Veldig enig

Barnet mitt er redd for å spise noe hun/han ikke har spist før

Barnet mitt vil spise nesten all slags mat

(1)

(1) på hva slags mat hun/han vil spise

Barnet mitt prøver stadig ny og ukjent mat

(1)
(1)
(2)
$\square$

(4)

(2)

(3)

(4)

(4)
(3)

(3)
(4)

Hvor mange ganger tilbyr du en ny matvare til barnet før du vurderer at barnet ikke liker maten?
(1) $\square$ En gang
(6) $\square$ To ganger
(5) $\square$ 3-5 ganger
(2) $\square$ 6-10 ganger
(3) $\square 11$ ganger eller mer

Nå kommer noen spørsmål om barnets matlyst og hvordan det oppleves å gi mat til barnet. Tenk på hvordan det har pleid å være den siste måneden når du svarer på spørsmålene.

Hvor enig eller uenig er du i følgende utsagn:

Helt uenig Litt uenig

Både og Litt enig Helt enig

Jeg må forsikre meg om at barnet ikke spiser for mye søtsaker (f.eks. godteri, is

(1)

eller kake, søt kjeks)

Jeg må forsikre meg om at barnet ikke spiser for mye fet mat

Jeg må forsikre meg om at
(2) $\square$

(3)

(4)

(5)

(1)

(2) $\square$

(3) $\square$

(4) $\square$

(5)

(1)

(2)

(3) $\square$

(4) $\square$

(5) 
barnet ikke spiser for mye av hans/ henne favorittmat

Jeg holder med hensikt noen typer mat unna barnet

(1)

$\square \quad$ (2)

(1) $\square$

(2)

(3)

(3)

4)

(5)

Jeg gir søtsaker (f.eks.

godteri, iskrem eller kaker) til barnet som belønning for god oppførsel

Jeg tilbyr barnet hans/ hennes favorittmat som belønning for god oppførsel
(1)

(2) $\square$

(3)

(4) $\square$

(5)

Hvor enig eller uenig er du i følgende utsagn:

Helt uenig Litt uenig

(1)

(2) $\square$

(1)

(2) $\square$

(3) $\square$

(4)

(4) $\square$

(5)

(3)

spist alt for mye usunn mat

Hvis jeg ikke regulerer

barnets spising, ville han/ hun spist alt for mye av sin favorittmat

Barnet bør (skal) alltid spise opp all maten på tallerken sin Jeg må passe spesielt på for å være sikker på at barnet spiser nok

Hvis barnet sier «jeg er ikke sulten» prøver jeg likevel å få han/ henne til å spise

Hvis jeg ikke regulerte barnets spising ville han/ hun (1) (1) $\square$

(2) $\square$

(2) $\square$

(3) $\square$

(4)

(4)

(5)

5)

(1)

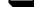

(3) $\square$

(4)

(5)
5)

Helt enig

spist alt for lite 
Og hvor ofte følger du med på..

..hvor mye søtsaker

(godterier, is, kaker/kjeks o.I.)

(1) $\square$

(2)

(3)

(4)

(5)

som barnet ditt spiser

..hvor mye snacks

(potetchips, ostepop o.I.) som

(1) $\square$

(2) $\square$

(3) $\square$

(4) $\square$

(5) $\square$

barnet ditt spiser?

..hvor mye fet mat som barnet

ditt spiser?

(1)

(2) $\square$

(3)

(4)

(5)

Her følger noen flere spørsmål om barnets spisevaner og matlyst og hvordan du forholder deg til det. Det er ingen "riktige" eller "gale" svar, vi er interessert i hva du som forelder virkelig føler og gjør.

\section{Hvor ofte stemmer utsagnene under?}

Aldri Sjelden Noen ganger Ofte $\quad$ Alltid

Jeg lar barnet mitt velge hva

slags mat hun/han vil ha til

(1) $\square$

(2) $\square$

(3)

(4)

(5)

måltider

Jeg gir barnet mitt noe å

spise for å føle seg bedre når hun/han føler seg opprørt

(1)

(2)

(3)

(4)

(5)

Jeg oppmuntrer barnet mitt til å glede seg til måltidet

(1)

(2)

(3) $\square$

(4)

(5) $\square$

Jeg roser barnet mitt hvis hun/han spiser det jeg gir henne/han

(1)

$\square$

(2) $\square$

(3) $\square$

(4) $\square$

(5) $\square$

Jeg bestemmer hvor mye snacks barnet mitt skal få

(1)

(2)

(3)

(4)

(5)

Jeg oppmuntrer barnet mitt til å spise mye forskjellig og
(1)

$\square \quad$ (2) $\square$

(2) $\square$

(3)

(4)

(5) 
variert mat

For å få barnet mitt til å oppføre seg fint, lover jeg henne/han noe å spise

(1)

(1)

(2)

(3) $\square$

(4)

5)

Jeg presenterer mat på en attraktiv måte for barnet mitt

(1)

(2) $\square$

(3) $\square$

(4)

(5)

Hvis barnet mitt oppfører seg dårlig, holder jeg tilbake favorittmaten hennes/hans
(1)

1) $\square$
(2)

(3) $\square$
(5)

Hvor ofte stemmer utsagnene under?

Aldri

(1)

(1)

(1) $\square$

har smakt før

Jeg gir barnet mitt noe å spise for å føle seg bedre når hun/han har slått seg

Jeg lar barnet mitt bestemme når hun/han vil spise måltidet sitt

(1)

1)

(2) $\square$

(2) $\square$

(2) $\square$

(2)

(3) $\square$

(3)

(3) $\square$

(4)

(4)

(5)

(5) 
Jeg lar barnet mitt bestemme når hun/han har spist nok snacks

Jeg bestemmer når det er tid for at barnet mitt kan spise en matbit/snack

(1)

(2)

(3) $\square$

(4)

(5)

Jeg bruker dessert som

belønning for å få barnet mitt

(1)

(2)

(3) $\square$

(4)

(5) $\square$

Hvor ofte stemmer utsagnene under?

Aldri

(1) $\square$

(1)

(1) $\square$

hun/han er bekymret

Jeg belønner barnet mitt med noe å spise når hun/han oppfører seg fint

(2) $\square$

(2) $\square$

(2) $\square$

(4)

(5)
(3) $\square$

(4) $\square$

(5) $\square$
(4)

(3) $\square$

(3) $\square$

(4)

(5)
Alltid

(5) $\square$

Jeg lar barnet mitt spise mellom måltidene når hun/han vil

Jeg insisterer på at barnet mitt spiser måltider ved

(1) $\square$

$\square$
(2) $\square$

(3) $\square$

(4) $\square$ 
Aldri Sjelden Noen ganger Ofte Alltid

bordet

Jeg gir barnet mitt noe å spise for å føle seg bedre når hun/han er sint

(1)

$\square$

(2)

$\square$

(3) $\square$

(4)

(5) $\square$

Jeg bestemmer hva barnet mitt spiser mellom måltider

Jeg roser barnet mitt når hun/han spiser ny mat
(1)

(2)

(1)

(1)

(2)

(3)

(4)

(5)

Nå kommer andre del av spørreskjemaet med spørsmål om deg som er mor eller far. Spørsmålene omhandler bakgrunnsopplysninger, matvaner og vurdering av egen fysisk og psykisk helse.

Hva er din fødselsdato?

Må skrives år-mnd-dato, f.eks, 1988-07-03

Har du, ev. mor til barnet som deltar i undersøkelsen, blitt gravid på ny etter at barnet som deltar i undersøkelsen ble født?
(1) $\square$ Nei
(2) $\square \mathrm{Ja}$, jeg er gravid nå
(3) $\square$ Ja, jeg har født barnet

Bor du sammen med barnets andre forelder?
(1) $\square \mathrm{Ja}$
(2) $\square \mathrm{Nei}$ 
Hvilken sivilstand har du nå?
(1) $\square$ Gift
(2) $\square$ Samboer
(3) $\square$ Enslig
(4) $\square$ Skilt/separert
(5) $\square$ Enke/enkemann
(6) $\square$ Annet, beskriv

\section{Hvilken utdannelse har du nå?}

\section{Velg høyeste fullførte utdanning}
(1) $\square$ Mindre enn $9 / 10$ års grunnskole
(2) $\square$ Grunnskole
(3) $\square$ Videregående skole
(4) $\square$ Videregående yrkesfag
(5) $\square$ Universitet/høyskole inntil 4 år
(6) $\square$ Universitet/høyskole mer enn 4 år
(7) $\square$ Annen utdanning

\section{Hva er din hovedaktivitet nå?}
(1) $\square$ Arbeid heltid
(2) $\square$ Arbeid deltid
(3) $\square$ Hjemmeværende
(4) $\square$ Sykemeldt
(5) $\square$ Permisjon
(6) $\square$ Uføretrygdet
(7) $\square$ Under attføring/rehabilitering
(8) $\square$ Student/skoleelev
(9) $\square$ Arbeidsledig
(10) $\square$ Annet

Er økonomien slik at du/dere vil ha mulighet til å klare en uforutsett regning på kr. 3000 til f. eks. tannlege eller en reparasjon?
(1) $\square \mathrm{Nei}$
(3) $\square \mathrm{Ja}$ 
(2) $\square$ Vet ikke

Har det i løpet av det siste året hendt at du/dere har hatt vansker med å klare løpende utgifter til mat, transport, husleie og lignende?
(1) $\square$ Nei
(2) $\square \mathrm{Ja}$
(3) $\square$ Vet ikke

Nå følger noen spørsmål om levevaner og livsstil:

Hvor mye veier du nå?

Svar i antall kg

Hvor høy er du? Svar i antall cm

\section{Røyker du?}
(1) $\square$ Nei, har aldri røykt regelmessig
(2) $\square$ Nei, har sluttet
(3) $\square$ Ja, men ikke daglig
(4) $\square$ Ja, daglig

\section{Snuser du?}
(1) $\square$ Nei, har aldri snust regelmessig
(2) $\square$ Nei, har sluttet
(3) $\square$ Ja, men ikke daglig
(4) $\square$ Ja, daglig 
Har du hovedansvaret for matlagingen hjemme?
(1) $\square$ Ja
(2) $\square \mathrm{Nei}$
(3) $\square$ Ansvaret er delt

\section{Hvor ofte gjør du følgende?}

\begin{tabular}{|c|c|c|c|c|c|c|}
\hline $\begin{array}{cc}\text { Mindre } \\
\text { dri } & \text { enn } 1 \\
& \mathrm{~g} / \mathrm{u}\end{array}$ & $1 \mathrm{~g} / \mathrm{u}$ & $2 \mathrm{~g} / \mathrm{u}$ & $3 \mathrm{~g} / \mathrm{u}$ & $4 \mathrm{~g} / \mathrm{u}$ & $5 \mathrm{~g} / \mathrm{u}$ & $6 \mathrm{~g} / \mathrm{u}$ \\
\hline
\end{tabular}

Kutter opp grønnsaker

(1) $\square \quad$ (2) $\square$ (3) $\square$ (4) $\square$ (5) $\square$ (6) $\square$ (7) $\square \quad$ (8) $\square$ (9) $\square$

Kutter opp frukt

(1) $\square \quad$ (2) $\square \quad$ (3) $\square \quad$ (4)

(4) $\square \quad$ (5)

(5) $\square \quad(6)$

(6) $\square \quad$ (7) $\square \quad(8)$

(8) $\square \quad$ (9) $\square$

Lager middag fra bunnen

(1) $\square \quad$ (2) $\square \quad$ (3) $\square \quad$ (4)

(4) $\square$

(6) $\square$

(7) $\square$

(8) $\square \quad$ (9) $\square$

Baker brød/rundstykker

(1) $\square \quad$ (2) $\square$

(3) $\square$

(4) $\square$

(5) $\square$

(6)

(7) $\square$

(8) $\square$

(9) $\square$

Da er du ferdig med å fylle ut skjemaet.

Du sender det inn ved å trykke på knappen under.

Tusen takk! 